\title{
Nederlandse aanspreekvormen bij Poolse NVT-taalleerders
}

\section{Dutch Forms of Address Among Students in Poland}

\author{
Muriel Waterlot
}

\begin{abstract}
This paper reports on a research on the use of Dutch forms of address (i.e. the second-person pronouns $u$ and je/jij) among students in Poland. It takes the address model proposed by Brown en Gilman and the findings of the research of Hannie Vermaas and Roel Vismans on the present use of Dutch forms of address in the Netherlands as its theoretical inspiration. Moreover it homes in on domain (as defined by Fishman and Clyne et al.) as factor for choice of address forms.

The paper is based on a quantitative analysis of a questionnaire in which Polish respondents of three universities in Poland were asked to point out which pronoun they use in order to address a variety of interlocutors. The research itself aims at finding out to what extend the Polish respondents are aware of the current sociolinguistic trends and changes in the use of forms of address in spoken Dutch in the Netherlands.
\end{abstract}

\section{Keywords}

Dutch forms of address, forms of address, second language learning, cross-cultural research 


\section{Inleiding}

In dit artikel breng ik verslag uit van een onderzoek naar het gebruik en de keuze van Nederlandse aanspreekvormen ${ }^{1}$ van de tweede persoon van Poolstalige universiteitsstudenten die Nederlands als vreemde taal leren aan een universiteit in Polen (hierna aangeduid als ,Poolstalige NVT-taalleerders' $)^{2}$. In het onderzoek wordt in het bijzonder nagegaan in hoeverre Poolstalige NVT-taalleerders zich bewust zijn van het Nederlandse sociolinguïstische systeem van aanspreken dat heel wat ongeschreven regels bevat (Salemans, 2005: 3) en hoofdzakelijk wordt gekenmerkt door een oprukkend gebruik van je en $j i j$ in situaties waarin we dit niet zouden verwachten (Salemans, 2005: 2). We kunnen ons hierbij de vraag stellen in welke mate Poolse NVT-taalleerders zich bewust zijn van deze ongeschreven regels. Ik besloot om dit na te gaan aan de hand van een vergelijking van het Nederlandse aanspreeksysteem van Poolse NVT-taalleerders en dat van Nederlandse studenten om te zien in hoeverre beide systemen verschillen. Ik ging daarbij uit van de veronderstelling dat de aanspreeksystemen van Poolse NVT-taalleerders en Nederlandse studenten verschillen vertonen en dat Nederlandse studenten frequenter de jevorm hanteren dan Poolse studenten.

Om de juistheid van deze veronderstelling of onderzoekshypothese te toetsen, maakte ik gebruik van het onderzoek van Hannie Vermaas (2002) en Roel Vismans (2013). Het onderzoek van Vermaas verstrekt ons namelijk waardevolle informatie over de veranderingen in het gebruik van aanspreekvormen in de spreektaal in $\mathrm{Ne}$ derland en dat van Vismans over het huidige gebruik van aanspreekvormen van de tweede persoon onder Nederlandse studenten. Hun onderzoek zal bijgevolg als referentiekader dienen om de geldigheid van de onderzoekshypothese na te gaan, en om het Nederlandse aanspreeksysteem van Poolse NVT-taalleerders te vergelijken met dat van Nederlandse studenten.

De gegevens voor het onderzoek naar het aanspreekgedrag van Poolse NVT-taalleerders zijn verzameld aan de hand van een in oktober en november 2014 gehouden enquête waarin ze gevraagd werden zich in te leven in de situatie dat ze in Nederland zijn, en aan te duiden welk voornaamwoord ze zouden gebruiken bij het aanspreken van diverse personen. Hanny Vermaas (2002) en Roel Vismans (2013) hanteerden in hun onderzoek een gelijkaardig onderzoeksinstrument. Omdat Vismans' onderzoek (2013) recente gegevens bevat over de hantering van $u$ en je/ jij onder Nederlandse universiteitsstudenten, maakte ik voor dit onderzoek gebruik van dezelfde enquête, op enkele inhoudelijke aanpassingen na die hierna in punt 3 nader zullen worden

1 Dit onderzoek houdt enkel verband met de aanspreekvormen van de tweede persoon van het Standaardnederlands, omdat dit de vormen zijn die in het onderwijs van het Nederlands als vreemde taal worden aangeleerd.

2 Dit artikel is gebaseerd is op een gelijkaardig onderzoek verricht op basis van dezelfde enquêtes en waarvan ik verslag uitbreng in het artikel ,Aanspreekvormen in het Nederlands van Poolstalige universiteitsstudenten' dat in oktober 2015 zal verschijnen en waarin het aanspreekgedrag in het Nederlands van Poolse BA-studenten en MA-studenten met elkaar wordt vergeleken. Vandaar dat er de inleiding en de bespreking van de theoretische achtergronden af en toe sprake is van herhaling of overlap. 
besproken. Dit vergemakkelijkte naderhand de vergelijking tussen het Nederlandse aanspreeksysteem van Poolse en Nederlandse studenten. Op basis van deze vergelijking kon dan uiteindelijk worden achterhaald of de hypothese geldig is en in welke mate Poolse NVT-taalleerders het huidige Nederlandse sociolinguïstische aanspreeksysteem beheersen.

Mijn analyse beperkt zich tot de aanspreekvormen van de tweede persoon enkelvoud in de onderwerpsvorm van de standaardtaal in Nederland, met name $u$ en $j e$, omdat dit de aanspreekvormen zijn die Nederlanders in het Standaardnederlands toepassen in dyadische vormen van interactie. In de onderstaande tabel zijn alle voornaamwoorden van de tweede persoon van het Standaardnederlands opgenomen; die van de tweede persoon - waarover sprake in dit artikel (cfr. je en $u$ ) - staan vetgedrukt:

Tabel 1: Voornaamwoorden van de tweede persoon van het Standaardnederlands

\begin{tabular}{|c|l|l|l|l|}
\hline & \multicolumn{2}{|c|}{ onderwerpsvorm } & \multicolumn{2}{c|}{ niet-onderwerpsvorm } \\
\hline enkelvoud & \multicolumn{1}{|c|}{ vol } & gereduceerd & \multicolumn{1}{c|}{ vol } & gereduceerd \\
\hline je-vormen & $\mathbf{j i j}$ & je & jou & je \\
\hline $\mathrm{u}$-vormen & $\mathbf{u}$ & $\mathrm{u}$ \\
\hline meervoud & \multicolumn{2}{l}{} \\
\hline je-vormen & $\mathrm{u}$ & jullie \\
\hline $\mathrm{u}$-vormen & $\mathrm{u}$ & $\mathrm{u}$ \\
\hline
\end{tabular}

In wat nu volgt, zal ik eerst de theoretische achtergronden bespreken aan de hand waarvan ik de onderzoekshypothese formuleerde. Vervolgens beschrijf ik de uitvoering van het enquêteonderzoek waarmee de hypothese getoetst is en bespreek ik de resultaten.

\section{Theoretische achtergronden en onderzoekshypothese}

Het theoretische kader van dit onderzoek wordt - zoals in de meeste onderzoeken over aanspreekvormen - ingegeven door de sociolingü̈stiek, met name het spraakmakende artikel van Roger Brown en Albert Gilman uit 1960 over , de voornaamwoorden van macht en solidariteit'. Zij schreven aan de pronomina van de tweede persoon een dubbele semantische waarde toe die wordt bepaald door de relatie tussen de spreker en de aangesprokene. Asymmetrisch gebruik van deze voornaamwoorden (de ene spreker gebruikt $u$, de andere $j e$ ) wordt gekenmerkt door $u$ naar de hogergeplaatste en $j e$ naar de lagergeplaatste en geeft op een talige manier uiting aan de maatschappelijke machtsverhoudingen tussen gesprekspartners. Symmetrisch gebruik van deze voornaamwoorden (wederzijds $u$ of $j e$ ) wordt daarentegen gekenmerkt door $u$ bij afwezigheid, en je bij aanwezigheid van solidariteit tussen hen.

Wat voor ons onderzoek van belang is, is hun theoretisch inzicht met betrekking tot de hantering van de $u$-vorm die thans in verband wordt gebracht met het scheppen van een ,zakelijke afstand' ( $u$ als distantiepronomen versus het voormalige $u$ als 
beleefdheidspronomen) en de je-vorm die thans geassocieerd wordt met de aanwezigheid van solidariteit tussen de gesprekspartners $(j e$ als solidariteitspronomen versus het voormalige $j e$ als informeel pronomen van de tweede persoon tegen gelijk- en zelfs hogergeplaatsten).

Deze verschuiving vond ook plaats in andere Europese talen, waaronder het Nederlands. Dit wordt ondermeer bevestigd in het onderzoek van Van den Toorn (1977: 528) en Hannie Vermaas (2002: 60). Volgens deze laatste is ,in vergelijking met vroeger de solidariteitsdimensie belangrijker geworden; ze kan nu als de dominante dimensie beschouwd worden' (Vermaas, 2002: 61). Vermaas komt onder meer tot deze conclusie in haar proefschrift over veranderingen in het gebruik van aanspreekvormen in de spreektaal in Nederland in de $20^{\text {ste }}$ eeuw. Daarmee werpt ze tevens licht op het huidige gebruik van deze vormen waaruit blijkt dat het gebruik van $u$ is teruggedrongen ten gunste van $j e / j i j$.

Vermaas constateert tevens dat het gebruik van aanspreekvormen tegenwoordig niet afdoende kan worden verklaard aan de hand van criteria zoals beleefdheid en vertrouwelijkheid en dat andere dimensies hier meespelen zoals status, solidariteit en formaliteit. Volgens haar hebben er blijkbaar sociaal-maatschappelijke veranderingen plaatsgevonden die de waardering van deze drie dimensies hebben beïnvloed. Ze stelt vast dat in onze tijd de dimensie solidariteit de overhand heeft gekregen en dat status en formaliteit minder belangrijk en zelfs ouderwets worden gevonden, wat vanzelf leidt tot een toename van het gebruik van jij als aanspreekvorm (2002: 23). Niettemin stelt Vermaas vast dat de nieuwe ongeschreven regels, waarbij die drie nieuwe dimensies (status, solidariteit en formaliteit) centraal staan, nog niet tot iedereen zijn doorgedrongen. Zeker niet bij de oudere generatie. Dit kunnen we bijvoorbeeld opmerken in het onderwijs waar veel oudere leerkrachten hun leerlingen hebben geleerd dat ze iemand uit beleefdheid met $u$ moeten aanspreken en die geconfronteerd worden met het oprukkende $j e$ en daarbij niet willen inzien dat de jij-zeggers niets onbeleefds bedoelen. Volgens Vermaas zitten we dus duidelijk in een overgangsfase die gekenmerkt wordt door botsingen tussen generaties (Salemans, 2005: 3).

Roel Vismans (2013) bouwt verder op het onderzoek van Vermaas en stelt aan de hand van een enquêteonderzoek onder Nederlandstalige universiteitsstudenten en hun (groot)ouders vast dat twee decennia later het jegebruik is toegenomen. Dit geldt niet alleen voor de aanspreking van familieleden en bekenden, maar ook voor werknemers uit bepaalde sectoren van de dienstverlening, vooral in de vrijetijdssector waar de spreker een grotere behoefte heeft dan in andere sectoren aan het vinden van common ground met zijn gesprekspartner tegenover wie hij zelfs verwacht dat hij de rol van vertrouwenspersoon vervult (Vismans, 2013: 183). In het onderwijs (secundair en hoger) en in iets zakelijkere verhoudingen constateert Vismans daarentegen geen toename van het $j$ egebruik.

Zijn onderzoek suggereert dat deze trend waarbij er vaker getutoyeerd wordt, zal worden voortgezet, hoewel sommige onderzoekers beweren dat de $u$-vorm in opmars is. Dit heeft volgens Vermaas (Salemans, 2005) te maken met het feit dat er Nederlanders zijn die zich afzetten tegen het oprukkende $j i j$ in bijvoorbeeld zakelijke gesprek- 
ken en die zich afvragen wat er eigenlijk mis is met het uitdrukken van statusverschil en waarom gesprekken bij voorkeur informeel moeten zijn. De $u$-vorm zal volgens Vermaas dus niet verdwijnen omwille van de behoefte die er bestaat om status te voelen of uit te drukken.

Bij het formuleren van de onderzoekshypothese met betrekking tot het Nederlandse aanspreeksysteem van Poolse studenten ging ik ervan uit dat ze vaker de formele aanspreekvorm $u$ hanteren dan Nederlandse studenten. Dit deed ik op basis van de bevindingen van het onderzoek van Marek Łaziński (2006) die beweert dat de power semantics of semantiek van de macht (waarbij het Pools vaak wordt bestempeld als een taal met een ,titelverslaving') in het Pools een belangrijkere rol speelt dan de semantiek van solidariteit (volgens de classificatie van Roger Brown en Albert Gilman) waardoor Polen bij het aanspreken van personen met macht of status gewoonlijk opteren voor formele aanspreekvormen. Aangezien er bij het leren van een vreemde taal sprake is van interferentie van moedertaal naar doeltaal (Kuiken, 2011), ging ik er bij het formuleren van de onderzoekshypothese (zie hieronder in punt 2.1.) van uit dat Poolse studenten, bij het aanspreken van personen met macht en status in het Nederlands, bijgevolg ook zullen kiezen voor formele aanspreekvormen.

\subsection{Onderzoekshypothese}

Om het gebruik van aanspreekvormen in het Nederlands van Poolstalige NVT-taalleerders te analyseren, formuleerde ik op basis van de constateringen van Vermaas (2002), Vismans (2013) en Łaziński (2006) de volgende onderzoekshypothese: het Nederlandse aanspreeksysteem van Nederlandse studenten is verschillend van dat van Poolse NVT-taalleerders: Nederlandse studenten hanteren frequenter de $j$ e-vorm dan Poolse NVT-taalleerders. Deze hypothese zal worden getoetst in de domeinen onderwijs en dienstverlening.

\section{Methodologie}

Om de geldigheid van de onderzoekshypothese te toetsen en de onderzoeksvraag te beantwoorden, stelde ik een enquête op op basis van de enquête die Vismans gebruikte voor zijn onderzoek naar het gebruik van $u$ en je/jij onder Nederlandse studenten en hun (groot)ouders (2013). In zijn enquête vraagt Vismans aan Nederlandse respondenten om aan te duiden welk voornaamwoord van de tweede persoon ze gebruiken bij het aanspreken van 20 gesprekspartners of relaties. Ze krijgen hierbij de mogelijkheid om te kiezen tussen $j e / j i j$, u, soms je/jij;soms $u$, en niet van toepassing.

In mijn enquête vroeg ik aan Poolse NVT-taalleerders om zich in te leven in de situatie dat ze in Nederland zijn en Nederlands moeten spreken met acht gesprekspartners of relaties uit de domeinen onderwijs en dienstverlening: (1) onderwijs: hoogleraar universiteit, docent universiteit ; (2) dienstverlening: tandarts, dokter, trainer, 
caissière supermarkt. Net als bijv Vismans, kregen ze de mogelijkheid om te kiezen tussen je/jij, u, soms je/jij;soms $u$, en niet van toepassing.

De selectie van de acht relaties gebeurde op grond van het feit dat uit de resultaten van de enquêtes is gebleken dat sommige Poolse respondenten moeite hadden om zich in te leven in de situatie waarin ze een docente of een rector van een middelbare school, familieleden en relaties van het domein ,bekenden' zoals de ouders van een goede vriend(in), de ouders van de partner, een buurman/-vrouw van ouders, een zakelijk relatie van ouders in het Nederlands zouden moeten aanspreken. Dit kon onder meer worden afgeleid van de hoge frequenties voor de optie ,niet van toepassing' voor deze relaties (cfr. gemiddeld $62 \%$ voor het domein ,familie' en $55 \%$ voor het domein ,bekenden').

In Vismans' onderzoek vertegenwoordigen de 20 relaties vier verschillende domeinen: familie (ooms/tantes, grootouders, ouders), onderwijs (docent middelbare school, hoogleraar universiteit, rector school, docent universiteit), bekenden (ouders partner, zakelijke relatie ouders, buurvrouw/-man ouders, ouders goede vriend(in)) en dienstverlening (huisbaas, loodgieter, dokter, trainer, tandarts, kroegbaas, caissière supermarkt, bakker, kapper). Het begrip ,domein' werd voor het eerst gebruikt door de socioloog Joshua Fishman (1972) toen hij taalkeuzes in meertalige gemeenschappen bestudeerde. De term werd door de Australische linguïst Michael Clyne (2009) overgenomen. Het gebruik van aanspreekvormen wordt in het model van Clyne mede bepaald door de contextuele factor ,domein'. Er bestaat in de sociolingü̈stiek geen vaste taxonomie van domeinen, maar Clyne concentreert zich op de familie, de school, de universiteit, het werk en zakelijk verkeer (met name interacties in winkels). Net als Vismans maak ik in mijn onderzoek gebruik van dit concept, doordat de relatie met de gesprekspartner centraal staat en het in dit geval zinvoller is om met een vragenlijst te werken waarin respondenten in gesprek gaan met een groter aantal gesprekspartners die deel uitmaken van één domein.

In haar onderzoek toont Vermaas (2002) aan dat bij de keuze van een aanspreekvorm voor de spreker de leeftijd, het geslacht, de opleiding en de godsdienst een belangrijke rol spelen, en voor de aangesprokene de leeftijd, het geslacht en de maatschappelijke positie. Bij de keuze van een aanspreekvorm tegenover enerzijds een arts en een tandarts, en anderzijds tegenover een trainer en een caissičre is het vanzelfsprekend dat de maatschappelijke positie een belangrijke rol zal spelen en dat een arts en een tandarts met een hogere positie eerder met $u$ zullen worden aangesproken. Wat de aanspreking van een arts en een trainer in Nederland betreft, is inderdaad uit de resultaten van het onderzoek van Vismans (2013) gebleken dat tegenover een arts de $u$-vorm het frequentst wordt gehanteerd $(84,7 \%)$ en voor een trainer de jevorm $(83,5 \%)$.

Daarentegen brachten de resultaten voor de aanspreking van een tandarts een statistisch significant generatieverschil aan het licht: tegenwoordig wordt een tandarts door de jongere generatie vaker met $j e$ aangesproken. Hiermee rekening houdend leek het mij interessant om ook deze relatie op te nemen in dit onderzoek. Dit geldt ook voor de relatie caissière, waarvan ik wou nagaan of er in Polen een 
even grote ambivalentie als in Nederland bestaat in de keuze van een passende aanspreekvorm.

De enquêtes werden verspreid onder Poolse studenten die Nederlands studeren aan de Universiteit van Wrocław (Uniwersytet Wrocławski), Poznań (Uniwersytet im. Adama Mickiewicza - UAM) en Lublin (Katolicki Uniwersytet Lubelski Jana Pawła II).

In de enquête werd eerst aan de respondenten gevraagd om een aantal vragen te beantwoorden die betrekking hebben op persoonlijke gegevens zoals hun studieniveau, leeftijd, geslacht en moedertaal of -talen. Bovendien werden ze gevraagd om te vermelden waar ze het langst hebben gewoond. Op basis van al deze gegevens konden de enquêtes worden geëlimineerd die ingevuld werden door respondenten die niet beantwoordden aan het verwachte profiel van een student met uitsluitend Pools als moedertaal en die het langst van zijn/haar leven in Polen heeft gewoond.

Op basis van de gegevens verkregen uit het antwoord op een reeks andere vragen zoals ,Ben je al eens in Nederland geweest (op vakantie bijvoorbeeld)?’, ,Heb je in Nederland gestudeerd?', ,Heb je een Nederlandse familie?', ,Heb je Nederlandse vrienden?', ,Heb je een Nederlandse vriend of vriendinnetje?' kon bij het bespreken van de onderzoeksresultaten en het formuleren van conclusies rekening worden gehouden. De antwoorden op dit soort vragen geven namelijk blijk van de mate waarin de respondenten in de werkelijkheid contact hebben of hebben gehad met Nederlanders en/of met de Nederlandse cultuur en maatschappij, wat invloed kan hebben op hun kennis van het huidige aanspreeksysteem in Nederland. Uit de antwoorden op deze vragen is gebleken dat $8 \%$ van de Poolse NVT-taalleerders in het buitenland gestudeerd heeft en dat $3 \%$ een Nederlandse vriend of vriendin heeft (cfr. tabel 2).

Tabel 2: Profiel Poolse respondenten: contact met Nederlanders /Nederlandse maatschappij en cultuur (in \%)

\begin{tabular}{|c|l|l|l|l|}
\hline $\begin{array}{l}\text { vakantie in } \\
\text { Nederland }\end{array}$ & $\begin{array}{l}\text { studie in } \\
\text { Nederland }\end{array}$ & $\begin{array}{l}\text { Nederlandse } \\
\text { vrienden }\end{array}$ & $\begin{array}{l}\text { Nederlandse vriend/ } \\
\text { vriendin }\end{array}$ & $\begin{array}{l}\text { Familie in } \\
\text { Nederland }\end{array}$ \\
\hline $79 \%$ & $8 \%$ & $4 \%$ & $3 \%$ & $0 \%$ \\
\hline
\end{tabular}

In totaal werden in de periode van 27 en 30 oktober 2014127 enquêtes terugbezorgd. 7 enquêtes werden geëlimineerd: 2 omwille van het feit dat de respondenten tweetalig waren, 5 omwille van het ontbreken van persoonlijke gegevens zoals het studieniveau en/of de moedertaal en/of de langste verblijfplaats.

Voor de 120 overige enquêtes werd voor de onderzochte relaties van de domeinen onderwijs en dienstverlening het gebruik van de drie aanspreekopties $j e / j i j, u$ en soms je/jij;soms $u$ in kaart gebracht op een spreadsheet. Daarna werden voor elk van de onderzochte domeinen en relaties de totalen vergeleken met de percentages van het gebruik van je/jij, $u$, soms je/jij-soms $u$ onder Nederlandse studenten uit Vismans' onderzoek (2013) (gegevens berekend op basis van 153 enquêtes). Deze resultaten 
werden tenslotte onderworpen aan een statistische toets, met name de G-test, met gebruikmaking van Excel. Dit is een algemene toets om vast te stellen of de gegevens statistische significantie hebben, en zo ja in welke mate. Bij de nu volgende analyse worden de uitkomsten van deze statistische toetsen gebruikt als extra ondersteuning.

\section{Onderzoeksresultaten: geldigheid van de onderzoekshypothese}

In de volgende paragrafen zal eerst de geldigheid van de hypothese worden getoetst voor de relaties van het domein onderwijs (cfr. 4.1.) en daarna voor deze van het domein dienstverlening (cfr. 4.2.).

\subsection{Onderwijs}

In het domein onderwijs werd aan de respondenten gevraagd om de aanspreekvormen aan te kruisen die ze gebruiken bij het aanspreken van een hoogleraar en een docent van de universiteit (zonder academische titel). In wat volgt zal de geldigheid van de hypothese worden getoetst voor deze twee relaties.

\subsubsection{Hoogleraar universiteit}

Diagram 1: Hoogleraar: aanspreekvormen in percentages: Poolse NVT-taalleerders versus Nederlandse studenten

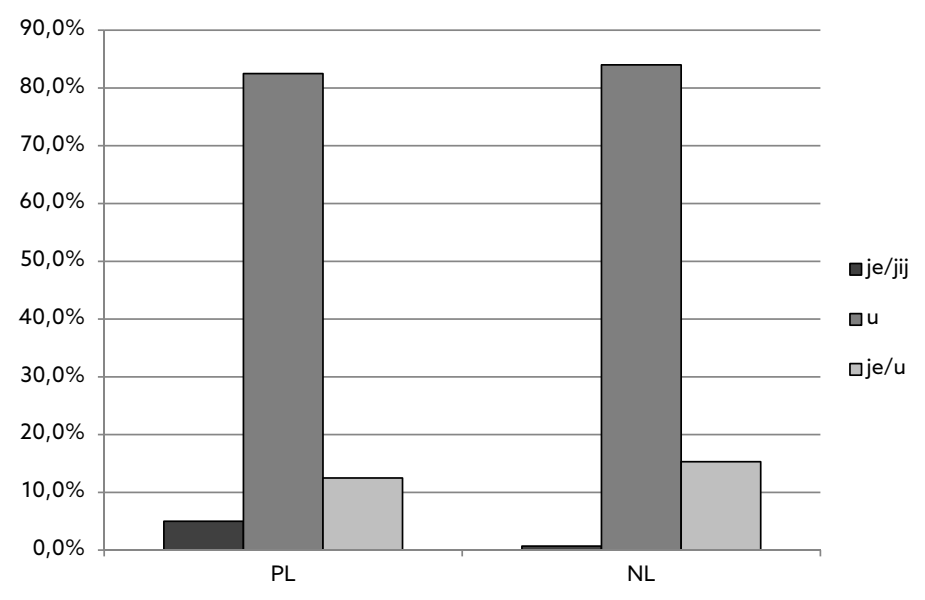

$\chi^{2}=5,57, \mathrm{df}=2, \mathrm{p}=0,1$

Wanneer we de percentages voor de aanspreking van een hoogleraar in diagram 1 onder de loep nemen, zien we dat studenten uit Nederland en Polen een hoogleraar op dezelfde manier aanspreken en vooral $u$ (cfr. PL: 82,5\% en NL: $84 \%$ ) hanteren. De 
aanspreekvorm je wordt daarentegen zowel door Poolse als Nederlandse studenten opvallend minder vaak gebruikt (cfr. PL: $5 \%$ en NL: 0,7\%). Wat echter ook opvalt, is dat de Poolse NVT-taalleerders hoger scoren op deze aanspreekvorm dan de Nederlandse studenten. Ook al lijkt het procentuele verschil tussen de $j e$ efrequenties van Polen en Nederland op het eerste gezicht onbeduidend (cfr. 4,3\% : Polen heeft een frequentie van $5 \%$ en Nederland van $0,7 \%$ ) is uit de statistische analyse gebleken dat dit verschil significant is. Bijgevolg kunnen we besluiten dat de onderzoekshypothese in het geval van een hoogleraar niet bevestigd is.

Niettemin kunnen we op basis van de scores van de u-aanspreking, die voor beide groepen respondenten het hoogst zijn, besluiten dat de Poolse NVT-taalleerders het huidige Nederlandse sociolingü̈stische systeem van aanspreken van deze relatie goed beheersen. Dit kunnen we ook besluiten op basis van de voor Polen voor de relatie hoogleraar (met status en macht) opmerkelijke hoge frequentie voor de je-aanspreking, vooral wanneer we voor ogen houden dat in Polen een hoogleraar door een student nooit met je wordt aangesproken en dat Polen een cultuur is waar in de aanspreking van een persoon met een bepaalde status naar functies of (academische) titels wordt verwezen (zoals bijvoorbeeld Panie Prezesie of ,meneer de Voorzitter', Panie Profesorze of ,meneer de Professor') om diens sociale status te benadrukken (Łaziński, $2006: 353)$.

Uit de resultaten blijkt dus echter ook dat Poolse NVT-taalleerders zich moeten behoeden om de in Nederland oprukkende je-vorm niet te veralgemenen tot een relatie met status en macht zoals een hoogleraar, omdat dit niet overeenstemt met de in Nederland geldende aanspreekpraktijk.

\subsubsection{Docent universiteit}

Diagram 2: Docent universiteit: aanspreekvormen in percentages: Poolse NVT-taalleerders versus Nederlandse studenten

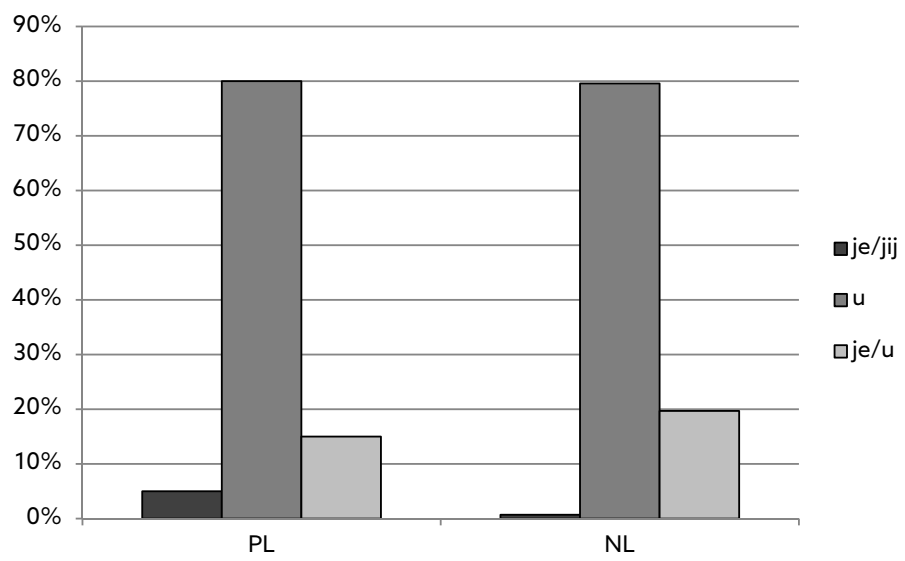

$\chi^{2}=6,10, \mathrm{df}=2, \mathrm{p}=0,05$ 
Wanneer we de aanspreking van een docent vergelijken met die van een hoogleraar, zien we een gelijkaardig scenario: uit de frequenties in diagram 2 kunnen we afleiden dat Poolse en Nederlandse studenten een universiteitsdocent vooral met $u$ aanspreken, en dat je zelden wordt gebruikt. Verder kunnen we opnieuw opmerken dat Poolse (cfr. 5\%) studenten vaker je hanteren dan Nederlandse. Aangezien uit de statistische analyse is gebleken dat het frequentieverschil significant is, is de hypothese ook voor deze relatie van het domein onderwijs niet bewezen.

Uit diagram 2 blijkt tot slot dat Polen, net als Nederland, betrekkelijk hoog scoort in de categorie $u / j e$ (cfr: Polen: $15 \%$; NL: 19,7\%). Uit het commentaar van de Poolse studenten bij deze optie kunnen we opmaken dat ze, net als de Nederlandse studenten, de keuze voor $j e$ of $u$ laten afhangen van de ,aanspreekvoorkeur' van de docent of van de manier waarop ze zelf door hem of haar worden aangesproken. Opvallend hierbij is dat dit op een significant grotere manier gebeurt dan in het geval van een hoogleraar (cfr. frequentie $u / j e$ : hoogleraar: $12,5 \%$; docent: $15 \%$ ). Op basis van deze gegevens, maar vooral op basis van dezelfde voorkeur die Poolse en Nederlandse studenten hebben voor de aanspreekvorm $u$, kunnen we besluiten dat Poolse NVT-taalleerders er zich bewust van zijn dat een universiteitsdocenten in Nederland hoofdzakelijk met $u$ wordt aangesproken, en dat er een iets grotere ambivalentie bestaat in de aanspreking van een universitair docent dan in die van een hoogleraar wat er op neerkomt dat, afhankelijke van de aanspreekvoorkeur van een docent, een docent vaker met ,je' kan worden aangesproken.

Aangezien slechts $8 \%$ van de Poolse respondenten in Nederland heeft gestudeerd (cfr. tabel 1), zouden de scores voor de $j e$ en $j e / u$-optie eventueel ook kunnen worden verklaard door factoren zoals bijvoorbeeld de afkomst van de universiteitsdocenten (krijgen ze colleges in het Nederlands en Nederlandse taallessen van Poolse of Nederlandse moedertaalsprekers uit Vlaanderen of Nederland?) of de door dezen gehanteerde aanspreeksystemen. Dergelijke factoren kunnen het Nederlandse aanspreeksysteem van de Poolse NVT-taalleerders namelijk ook beïnvloeden. Dit onderwerp vormt een aanzet voor verder onderzoek.

\subsection{Dienstverlening}

In de volgende paragrafen zullen we nagaan of de hypothese geldig is voor de aanspreking van de vier relaties uit het domein dienstverlening: dokter, tandarts, trainer en supermarktcaissière.

\subsubsection{Dokter}

Zoals reeds vermeld onder punt 3 scoort Nederland volgens de onderzoeksresultaten van Vismans (2013) in het domein ,dienstverlening' het hoogst op de $u$-vorm in de aanspreking van de relatie dokter. Wanneer we de percentages in diagram 3 onder de 
loep nemen, zien we dat ook uit ons enquête-onderzoek blijkt dat Nederland hoog scoort op deze aanspreekvorm, namelijk met een frequentie van $84,7 \%$. Wanneer we dit percentage vergelijken met dat van Polen, kunnen we opmerken dat ook de Poolse NVT-taalleerders deze aanspreekvorm het vaakst hanteren (cfr. 86,7\%).

Wanneer we daarentegen de percentages voor de je-aanspreking voor Polen en Nederland met elkaar vergelijken, zien we dat deze vorm zelden wordt gebruikt voor de aanspreking van een arts (cfr. PL: 6\% ; NL: 4,2\%). Ook al scoort Polen iets hoger op deze aanspreekvorm dan Nederland, blijkt uit de resultaten van de statistische toets dat het verschil niet significant is. Vandaar dat de geldigheid van de hypothese niet kan worden bevestigd.

Tot slot kunnen we uit de percentages voor de optie $j e / u$ afleiden dat Poolse en Nederlandse studenten haast dezelfde frequentie vertonen (cfr. PL: 9,2\% versus NL: $9,3 \%)$. Ook in dit geval is uit de G-test gebleken dat het verschil niet significant is, wat aangeeft dat de ambivalentie in Polen en Nederland even groot is. Uit het commentaar van de Poolse studenten is gebleken dat de jevorm uitsluitend wordt aangewend in het geval van een goede, lange of vriendschappelijke relatie met een arts.

Aangezien uit de resultaten van de aanspreking van een arts is gebleken dat zowel Nederlandse en Poolse studenten vooral $u$ hanteren voor de aanspreking van een arts, en dat beide groepen respondenten bovendien met eenzelfde frequentie je toepassen, kunnen we besluiten dat Poolse NVT-taalleerders het huidige Nederlandse aanspreeksysteem van deze relatie goed beheersen.

Diagram 3: Dokter: aanspreekvormen in percentages: Poolse NVT-taalleerders versus Nederlandse studenten

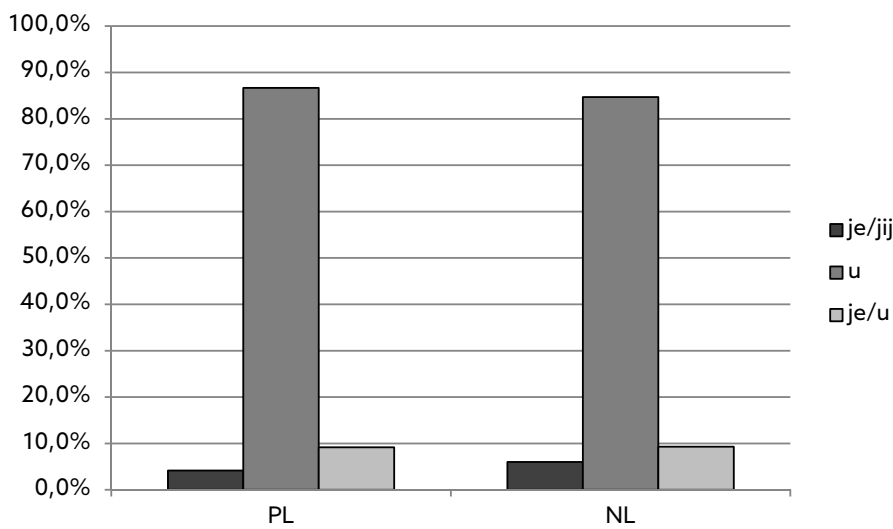

$\chi^{2}=0,47, \mathrm{df}=2$ 


\subsubsection{Tandarts}

Diagram 4: Tandarts: aanspreekvormen in percentages: Poolse NVT-taalleerders versus Nederlandse studenten

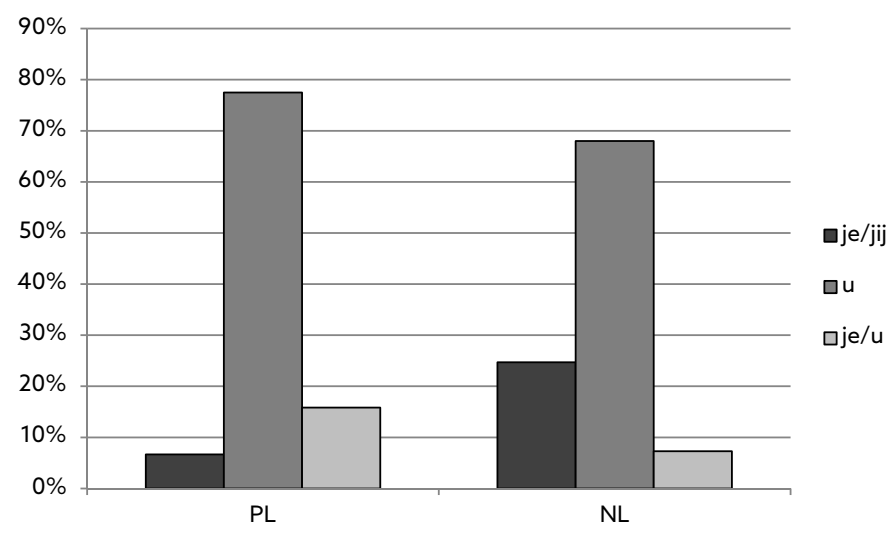

$\chi^{2}=19,50, \mathrm{df}=2, \mathrm{p}=0,001$

Wanneer we in diagram 4 de percentages van de aanspreking van een tandarts voor Polen en Nederland met elkaar vergelijken, zien we dat zowel Poolse als Nederlandse studenten hoofdzakelijk $u$ hanteren, en dat Poolse studenten dit met een hogere frequentie doen dan Nederlandse (cfr. PL: 77,5\% versus NL: 68\%). Nederlandse studenten hanteren daarentegen vaker de $j$-aanspreking dan Poolse (cfr. NL: 24,7\% versus $6,7 \%$ ), waardoor de geldigheid van de hypothese voor de aanspreking van deze relatie is bevestigd.

Uit de percentages van de optie $j e / u$ kunnen we ook afleiden dat er in Polen een grotere ambivalentie bestaat dan in Nederland in de keuze van je of $u$ die - zoals blijkt uit de commentaren van de studenten - afhankelijk is van de aard of duur van de relatie die Poolse studenten hebben met een tandarts. Bij de Nederlandse studenten is die ambivalentie in de keuze van een aanspreekvorm (cfr. 7,3\%) duidelijk minder aanwezig: Nederlandse studenten hanteren of $j e$ of $u$, met een uitgesproken voorkeur voor $u$.

\subsubsection{Trainer}

De percentages in diagram 5 tonen aan dat zowel de Nederlandse als de Poolse studenten een trainer vooral met $j e$ aanspreken, en dat Nederlandse studenten dit opmerkelijk frequenter doen dan Poolse (cfr. PL: 50\% versus NL: 83,50\%) waardoor de geldigheid van de hypothese voor deze relatie bevestigd is. Daarnaast zien we dat Polen hoger dan Nederland scoort in de $u$-aanspreking (cfr. PL: 18,3\% versus NL: $7,80 \%$ ) en in de optie $j e / u$ (cfr. PL: $31,7 \%$ versus NL: 8,70\%). De frequenties van de 
$j e / u$-optie tonen aan dat in Nederland de keuze van een aanspreekvorm voor een trainer minder ambivalent is dan in Polen: Nederlandse studenten hanteren in de meeste gevallen gewoon $\mathrm{je}$. Bij de Poolse studenten ligt de keuze duidelijker gevoeliger en is die - volgens het commentaar van de respondenten - afhankelijk van factoren zoals o.a. bekendheid, aard van de relatie, leeftijd van de trainer edm.

Diagram 5: Trainer: aanspreekvormen in percentages: Poolse NVT-taalleerders versus Nederlandse studenten

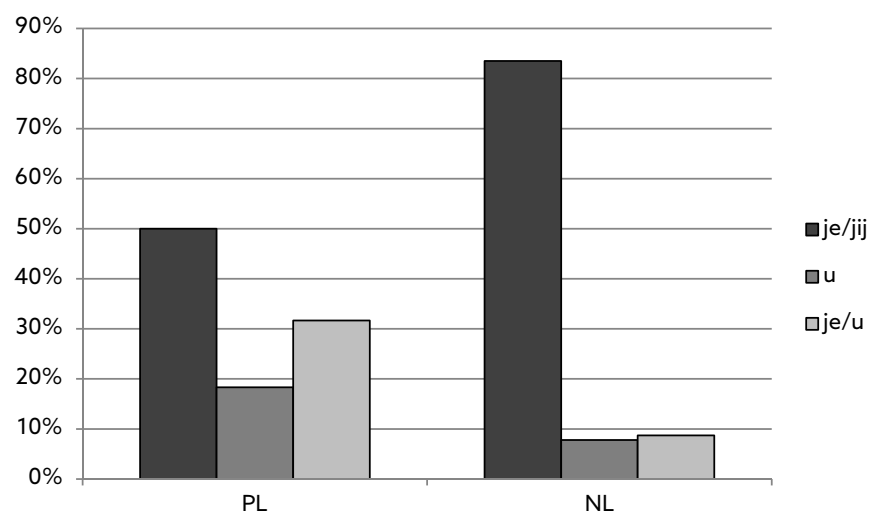

$\chi^{2}=36,17, \mathrm{df}=2, \mathrm{p}=0,001$

\subsubsection{Caissière supermarkt_}

Diagram 6: Caissière supermarkt: aanspreekvormen in percentages: Poolse NVT-taalleerders versus Nederlandse studenten

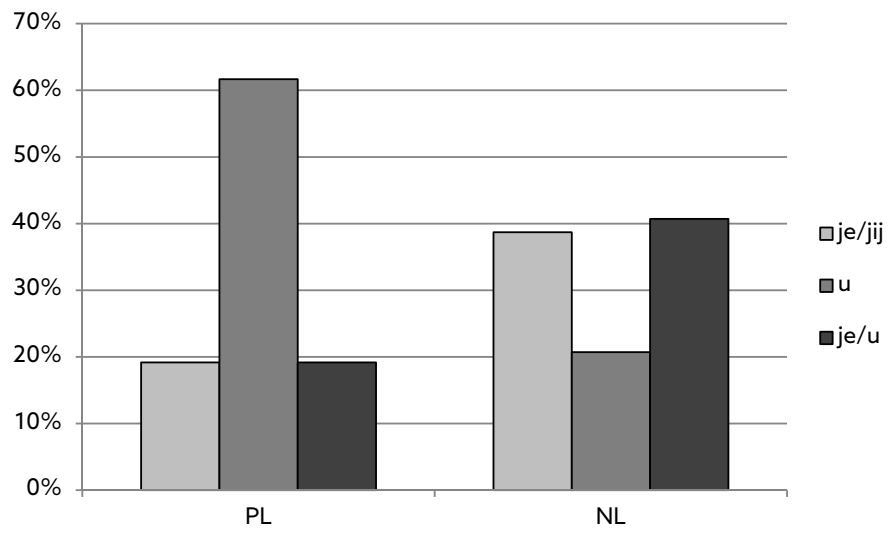

$\chi^{2}=44,03, \mathrm{df}=2, \mathrm{p}=0,001$ 
Wanneer we de percentages voor de aanspreking van een caissière in diagram 6 bekijken, zien we dat Nederlandse studenten vaker je dan $u$ hanteren, en Poolse studenten vaker $u$ dan $j e$ (cfr. NL: je/jij: 38,70\% ; u: 20,70\% versus PL:je/jij: 19,2\% ; u: 61,7\%). Aangezien Nederland hoger scoort dan Polen op de $j e$-aanspreking, is de geldigheid van de hypothese bewezen.

Een ander opmerkelijk verschil tussen Polen en Nederland is dat in Nederland aanspreking van een caissière in Nederland opvallend meer ambivalentie vertoont. Een mogelijke verklaring hiervoor vinden we in het onderzoek van Vismans: bij het kiezen een passende aanspreekvorm voor een caissière laten Nederlandse studenten zich leiden door factoren zoals, vriendelijkheid' en ,leeftijd'. Verder hechten ze ook belang aan de manier waarop ze zelf door een caissière worden aangesproken: ,als ik aangesproken word met je, antwoord ik met je; met $u$, zeg ik ook $u$.'(Vismans, 2013). Bij een trainer ligt dit anders: die wordt vaak gewoon met je aangesproken, omdat de graad van vertrouwelijkheid groter is dan in het geval van een caissière.

In tegenstelling tot Nederland is de ambivalentie in de aanspreking van een caissière en een trainer in Polen haast even groot. Toch kon uit de meerderheid van commentaren voor de $j e / \mathrm{u}$-optie van de Poolse studenten worden opgemaakt dat ze in het geval van een caissière de hantering van $u$ gepaster vinden, wat bijvoorbeeld duidelijk tot uiting komt in de volgende uitspraak: ,ook als ik deze persoon persoonlijk zou kennen, zou ik verlegen zijn om je te gebruiken'. (BA III, 12). Op basis van deze constatering en tevens op grond van de vastgestelde verschillen die Poolse en Nederlandse studenten vertonen in de aanspreking van een caissière in het Nederlands, kunnen we concluderen dat Poolse NVT-taalleerders minder goed vertrouwd zijn met het huidige Nederlandse sociologische aanspreekgedrag van dit type relatie.

\section{Conclusie}

Uit de resultaten van dit onderzoek is gebleken dat de hypothese in de onderzochte domeinen en relaties geldig is in alle onderzochte relaties van het domein dienstverlening, met uitzondering van de aanspreking van een arts. Dit betekent dat Nederlandse studenten in dit domein dus wel degelijk vaker je hanteren dan Poolse, behalve in het geval van een arts die zowel door Polen als Nederlanders, even zelden' met je wordt aangesproken.

De meest opmerkelijke verschillen in de frequenties van de $j$ eaanspreking tussen Poolse en Nederlandse studenten treffen we aan in de aanspreking van een trainer en een caissière, waar Poolse studenten opmerkelijk minder vaak je hanteren dan $\mathrm{Ne}$ derlandse. Poolse studenten hanteren , $j e$ ' wanneer ze een trainer of caissière goed kennen, of wanneer hij of zij jonger is. Dit in tegenstelling tot Nederlandse studenten die meestal je hanteren voor een trainer, en dit ook doen voor een caissière wanneer die jong en vriendelijk is.

Ook al vertonen Poolse en Nederlandse studenten frequentieverschillen in de aanspreking van de onderzochte relaties, kunnen we - met uitzondering van de caissière 
waar Polen het hoogste scoort op $u$ en Nederland op je/u - dat ze voor alle onderzochte relaties voornamelijk dezelfde aanspreekvorm hanteren, wat aantoont dat de Poolse NVT-taalleerders zich in grote mate bewust zijn van het huidige Nederlandse aanspreeksysteem dat geldt voor de onderzochte relaties van het domein dienstverlening. Dit komt vooral tot uiting in de aanspreking van een trainer, waar we zouden verwachten dat Poolse studenten eerder voor de $u$-vorm zouden opteren, zoals ze dat doen voor een caissière.

In de onderzochte relaties van het domein onderwijs is de geldigheid van de hypothese niet aangetoond: zowel in de aanspreking van een hoogleraar als in de aanspreking van een docent gebruiken Poolse NVT-taalleerder frequenter de jevorm dan Nederlandse.

Uit de resultaten voor de meest frequent gehanteerde aanspreekvormen voor deze twee relaties, kon daarentegen worden opgemaakt dat Poolse NVT-taalleerders zich ervan bewust zijn dat een hoogleraar en een universiteitsdocent meestal met $u$ worden aangesproken. Bovendien is uit de commentaren bij de optie $j e / u$ gebleken dat ze er zich ook van bewust zijn dat voor beide relaties en in concrete gevallen ook jekan worden gebruikt, waardoor we kunnen besluiten dat Poolse NVT-taalleerders goed op de hoogte zijn van het huidige Nederlandse sociolinguïstische aanspreeksysteem. De hogere frequenties van de je-aanspreking bij de Poolse NVT-taalleerders doet ons echter vermoeden dat hun aanspreekgedrag wordt beïnvloed door het aanspreekgedrag of de afkomst van hun eigen docenten (cfr. krijgen ze colleges in het Nederlands en Nederlandse taallessen van Poolse of Nederlandse moedertaalsprekers uit Vlaanderen of Nederland?) wat een aanzet vormt voor verder onderzoek.

\section{Bibliografie}

BROWN, R., GILMAN, A. (1960): 'The pronouns of power and solidarity'. Style in language. Sebeok (ed.). T.A. Boston: MIT Press, p. 253-76.

CLYNE, M. (2009): Language and Human Relations. Styles of Address in Contemporary Language. Cambridge: Cambridge University Press.

FISHMAN, J. (1972): 'Domains and the Relationship between Micro- and Macrosociolinguistics'. Directions in Sociolinguistics. The Ethnography of Communication. ed. by John J. Gumperz and Dell Hymes. Oxford: Blackwell, p. 435-53.

KUIKEN, F. (2011): ,(Vreemde)taalverwerving en de contrastieve aanpak'. $N / F-$ Association des Néerlandistes de Belgique francophone, Vol. 10, p. 13-26.

ŁAŻIŃSKI, M. (2006): O panach i paniach, polskie rzeczowniki tytularne i ich asymetria rodzajopłciowa. Warszawa: Wydawnictwo Naukowe PWN.

MARCJANIK, M. (2008): Grzeczność w komunikacji jezykowej. Wydawnictwo Naukowe PWN, Warszawa.

SALEMANS, B. (2005): ,Steeds minder mensen zeggen $u$ '. Reportage. Taalschrift juni/juli 2005, p. 1-5.

TOORN, M.C. van den. (1977): ,De problematiek van de Nederlandse aanspreekvormen'. Nieuwe Taalgids 70. p. 520-540. 
VERMAAS, J.A.M. (2002): Veranderingen in de Nederlandse aanspreekvormen van de dertiende $t / m$ de twintigste eeuw. Utrecht: LOT.

VISMANS, R. (2013): 'Address Choice in Dutch 1: Variation and the Role of Domain'. Dutch Crossing. A Journal of Low Countries Studies 37.2. p. 163-187.

Muriel Waterlot / murielwaterlot@kul.pl

Katolicki Uniwersytet Lubelski Jana Pawła II, Wydział Nauk Humanistycznych, Katedra Literatury i Języka Niderlandzkiego

Al. Racławickie 14, 20-950 Lublin, Poland 